\title{
Sistem Penentuan Penerimaan Beasiswa Di SMA PGRI 4 Jakarta Timur
}

\author{
Septiana Utari ${ }^{1}$, Santoso Setiawan ${ }^{2}$ \\ ${ }^{1,2}$ Universitas Nusa Mandiri \\ e-mail: ${ }^{1}$ utari0040@ gmail.com, ${ }^{2}$ santoso.sts@ nusamandiri.ac.id

\begin{tabular}{ccc}
\hline Diterima & Direvisi & Disetujui \\
$24-10-2021$ & $01-11-2021$ & $03-11-2021$ \\
\hline
\end{tabular}

\begin{abstract}
Abstrak - Beasiswa dapat dikatakan sebagai pembiayaan yang tidak bersumber dari pendanaan sendiri atau orang tua, tetapi diberikan oleh pemerintah, perusahaan, kedutaan, universitas, serta lembaga pendidik atau peneliti. Biaya tersebut diberikan kepada yang berhak menerima sesuai dengan kriteria yang ditentukan, demikian halnya dengan SMA PGRI 4 Jakarta Timur yang telah memiliki program pemberian beasiswa terhadap siswa-siswinya. Beasiswa harus diberikan kepada penerima yang layak dan pantas untuk mendapatkannya. Akan tetapi, dalam melakukan seleksi beasiswa tersebut tentu akan mengalami kesulitan karena banyaknya pelamar beasiswa dan adanya beberapa kriteria yang digunakan untuk menentukan siapa penerima beasiswa yang sesuai dengan yang diharapkan, maka dibutuhkan sistem pendukung keputusan. Salah satu metode yang akan digunakan adalah metode Simple Additive Weighting (SAW). Penetapan kriteria penerima beasiswa ditentukan dari penghasilan orang tua, total nilai semester, tanggungan orang tua, dan ranking kelas. Penelitian ini juga menghasilkan sistem yang mampu menampilkan rekomendasi calon penerima beasiswa dengan hasil bobot kriteria dan preferensi yang ditentukan oleh kebutuhan sistem.
\end{abstract}

Kata Kunci: Simple Additive Weighting, sistem pendukung keputusan, beasiswa.

\begin{abstract}
Scholarships can be considered as financing that does not come from own or parental funding, but is provided by the government, companies, embassies, universities, as well as educational or research institutions. The fee is given to those who are entitled to receive it according to the specified criteria, as is the case with SMA PGRI 4 East Jakarta which already has a scholarship program for its students. Scholarships must be awarded to deserving recipients and are deserving of them. However, in conducting the scholarship selection, it will certainly experience difficulties because of the large number of scholarship applicants and the existence of several criteria used to determine who the scholarship recipients are expected to be, so a decision support system is needed. One method that will be used is the Simple Additive Weighting (SAW) method. The criteria for scholarship recipients are determined from the income of the parents, the total semester grades, the dependents of the parents, and the class ranking. This research also produces a system that is able to display the recommendations of prospective scholarship recipients with the results of the weighting of criteria and preferences determined by the needs of the system.
\end{abstract}

Keywords: Simple Additive Weighting, decision support system, scholarship.

\section{PENDAHULUAN}

Menyadari bahwa pendidikan sangat penting, negara sangat mendukung setiap warga negaranya untuk meraih pendidikan setinggi-tingginya. Beberapa di antaranya melakukan program pendidikan gratis dan program beasiswa. Beasiswa dapat dikatakan sebagai pembiayaan yang tidak bersumber dari pendanaan sendiri (Mulyadi \& Prairawan, 2020) atau orang tua, akan tetapi diberikan oleh pemerintah, perusahaan swasta, kedutaan, universitas, serta lembaga pendidik atau peneliti. Biaya tersebut diberikan kepada yang berhak menerima sesuai dengan kriteria yang ditentukan (H. Saputra, Mardiono, Stephane, \& Purwasih, 2021).

Demikian halnya dengan SMA PGRI 4 Jakarta Timur yang telah memiliki program pemberian beasiswa terhadap siswa-siswinya. Beasiswa harus diberikan kepada penerima yang layak dan pantas untuk mendapatkannya (Putra, Zaliluddin, \& Abdurahman, 2018). Akan tetapi, dalam melakukan seleksi beasiswa tersebut tentu akan mengalami kesulitan (R. D. Saputra, Erwandi, \& Khoir, 2017) karena banyaknya pelamar beasiswa dan adanya beberapa kriteria yang digunakan untuk menentukan siapa penerima beasiswa yang sesuai dengan yang diharapkan. Tidak semua yang mendaftarkan diri sebagai calon penerima beasiswa akan diterima (H. Saputra et al., 2021), hanya yang memenuhi kriteria-kriteria saja yang akan memperoleh beasiswa tersebut.

Permasalahan tersebut dapat ditangani dengan dibuatnya sebuah sistem penunjang keputusan. Pengambilan keputusan dilakukan dengan pendekatan sistematis (Narti, Sriyadi, Rahmayani, \& Syarif, 2019) terhadap permasalahan melalui proses pengumpulan data menjadi informasi serta ditambah dengan faktor-faktor yang perlu dipertimbangkan dalam pengambilan keputusan 
(Amri, 2018) dengan rumus-rumus tertentu sehingga perhitungannya lebih akurat. Dalam kasus ini akan digunakan metode Simple Additive Weighting (SAW). SAW adalah salah satu metode pengambilan keputusan kriteria majemuk (Fauzan, Indrasary, \& Muthia, 2018) pada suatu masalah yang memiliki lebih dari satu kriteria (multikriteria). Dugaan dari dominasi kriteria yang digunakan dalam metode Simple Additive Weighting (SAW) adalah penggunaan nilai dalam hubungan outranking (Karim \& Karim, 2018) . Semua parameter yang dinyatakan mempunyai pengaruh nyata menurut pandangan ekonomi (Handayani \& -, 2018). Pemilihan metode SAW dipilih karena merupakan suatu metode penentuan urutan (prioritas) yang lebih sederhana dalam analisa multi kriteria (Efendi \& Ali, 2019), lebih jelas dalam perhitungan dan proses analisanya sehingga diharapkan dapat menjadi solusi bagi permasalahan pemilihan beasiswa di SMA PGRI 4 Jakarta Timur.

\section{METODE PENELITIAN}

1. Identifikasi Masalah

Melakukan identifikasi pada suatu masalah merupakan tahap awal pada proses penelitian. Tahap ini dibangun berdasarkan rumusan masalah yang didasari atas latar belakang masalah.

2. Studi literatur

Dilakukan dengan mempelajari dan memahami teori-teori yang digunakan, yaitu diantaranya mencari faktor-faktor yang menjadi syarat sistem pendukung keputusan, metode Simple Additive Weighting (SAW) dan metode pengumpulan data. Data-data tersebut dicari dengan cara mengumpulkan literatur, jurnal nasional, browsing internet dan bacaan-bacaan yang ada kaitannya dengan topic baik berupa textbook atau paper.

3. Pengumpulan Data

Tahap ini merupakan cara mengumpulkan data yang dilakukan dengan cara membagikan kuesioner kepada Bagian Kesiswaan dan kepala sekolah SMA PGRI 4 Jakarta Timur.

4. Tahap Analisis Data

Kuesioner yang sudah diisi diberi nilai sesuai ketentuan akan diolah dengan rumus metode yang akan digunakan hingga ditemukan hasilnya.

5. Hasil Analisa Data

Tahap analisis data dengan menggunakan metode Simple Additive Weighting (SAW) dihasilkan suatu hasil analisis yang merupakan hasil dari suatu proses penelitian yang dilakukan.

6. Kesimpulan dan saran

Kesimpulan merupakan tahapan akhir dari uraian proses penelitian dengan menyimpulkan permasalahan yang ada.

\section{HASIL DAN PEMBAHASAN}

Berikut adalah kriteria-kriteria yang dibutuhkan untuk mengukur dan menilai pemberian beasiswa.

1. Penghasilan orang tua

Indikator yang digunakan dalam penentuan pemberian beasiswa ini berdasarkan penghasilan orang tua murid.

Tabel 1. Kriteria Penghasilan Orang Tua

\begin{tabular}{|c|c|c|}
\hline Kriteria & Range & Bobot \\
\hline \multirow{4}{*}{$\begin{array}{c}\text { Penghasilan } \\
\text { orang tua }\end{array}$} & $>5.000 .000$ & 1 \\
\cline { 2 - 3 } & $3.000 .000-5.000 .000$ & 2 \\
\cline { 2 - 3 } & $1.000 .000-3.000 .000$ & 3 \\
\cline { 2 - 3 } & $500.000-1.000 .000$ & 4 \\
\cline { 2 - 3 } & $<500.000$ & 5 \\
\hline
\end{tabular}

Sumber: Hasil Penelitian (2021)

\section{Total Nilai Semester}

Indikator yang digunakan dalam penentuan pemberian beasiswa ini berdasarkan total nilai semester siswa.

Tabel 2. Kriteria Total Nilai Semester

\begin{tabular}{|c|c|c|}
\hline Kriteria & Range & Bobot \\
\hline \multirow{4}{*}{ Total nilai semester } & $90-100$ & 5 \\
\cline { 2 - 3 } & $70-90$ & 4 \\
\cline { 2 - 3 } & $60-70$ & 3 \\
\cline { 2 - 3 } & $50-60$ & 2 \\
\cline { 2 - 3 } & $<50$ & 1 \\
\hline
\end{tabular}

Sumber: Hasil Penelitian (2021)

\section{Tanggungan Orang Tua}

Indikator yang digunakan dalam penentuan pemberian beasiswa ini berdasarkan tanggungan orang tua siswa.

Tabel 3. Kriteria Tanggungan Orang Tua

\begin{tabular}{|c|c|c|}
\hline Kriteria & Range & Bobot \\
\hline Tanggungan orang tua & 1 Anak & 1 \\
\cline { 2 - 3 } & 2 Anak & 2 \\
\cline { 2 - 3 } & 3 Anak & 3 \\
\cline { 2 - 3 } & 4 Anak & 4 \\
\cline { 2 - 3 } & 5 Anak & 5 \\
\hline
\end{tabular}

Sumber: Hasil Penelitian (2021)

\section{Ranking Kelas}

Indikator yang digunakan dalam penentuan pemberian beasiswa ini berdasarkan Ranking Kelas.

Tabel 4. Kriteria Ranking Kelas

\begin{tabular}{|c|c|c|}
\hline Kriteria & Range & Bobot \\
\hline \multirow{4}{*}{ Ranking kelas } & $1-5$ & 5 \\
\cline { 2 - 3 } & $6-10$ & 4 \\
\cline { 2 - 3 } & $11-15$ & 3 \\
\cline { 2 - 3 } & $15-25$ & 2 \\
\cline { 2 - 3 } & $25-40$ & 1 \\
\hline
\end{tabular}

Sumber: Hasil Penelitian (2021) 
Setelah membuat beberapa tabel kriteria, langkah berikutnya adalah membuat bobot preferensi $(\mathrm{W})$ sebagai berikut:

$\mathrm{W} 1=$ Penghasilan Orang Tua $(40 \%)=0,4$

$\mathrm{W} 2=$ Total Nilai Semester $(30 \%)=0,3$

W3 = Tanggungan Orang Tua $(20 \%)=0,2$

W4= Ranking Kelas $(10 \%)=0,1$

Langkah berikutnya adalah membuat penilaian terhadap calon penerima beasiswa.

Tabel 5. Nilai dari Masing-masing kriteria

\begin{tabular}{|c|c|c|c|c|}
\hline \multirow[b]{2}{*}{ NAMA } & \multicolumn{4}{|c|}{ KRITERIA } \\
\hline & $\begin{array}{c}\text { Penghasil } \\
\text { an Orang } \\
\text { Tua }\end{array}$ & $\begin{array}{c}\text { Total } \\
\text { Nilai } \\
\text { Semest } \\
\text { er }\end{array}$ & $\begin{array}{c}\text { Tanggun } \\
\text { gan } \\
\text { Orang } \\
\text { Tua }\end{array}$ & $\begin{array}{c}\text { Ranki } \\
\text { ng } \\
\text { Kelas }\end{array}$ \\
\hline Jaya Kusuma & 450.000 & 70 & 3 & 3 \\
\hline Rasyid Alvian & 800.000 & 65 & 5 & 12 \\
\hline Una Wardani & 2.500 .000 & 70 & 3 & 14 \\
\hline $\begin{array}{ll}\text { Eva } & \text { Natashya } \\
\text { Putri } & \\
\end{array}$ & 500.000 & 90 & 2 & 8 \\
\hline Dini Nuarini & 8.000 .000 & 40 & 2 & 7 \\
\hline Laura Natazhya & 300.000 & 80 & 2 & 9 \\
\hline $\begin{array}{l}\text { Antonius } \\
\text { Lumban Gaol }\end{array}$ & 4.500 .000 & 55 & 1 & 3 \\
\hline Rudy Chandra & 350.000 & 85 & 2 & 8 \\
\hline Julian Pakpahan & 400.000 & 60 & 2 & 9 \\
\hline $\begin{array}{ll}\text { Arif } & \text { Taufik } \\
\text { Ritonga } & \\
\end{array}$ & 850.000 & 95 & 3 & 13 \\
\hline $\begin{array}{l}\text { Rachman } \\
\text { Fadillah }\end{array}$ & 2.500 .000 & 60 & 5 & 6 \\
\hline Fauzi Fuad & 400.000 & 85 & 3 & 15 \\
\hline Dwi Prasetya & 800.000 & 65 & 3 & 12 \\
\hline Tri Budiawan & 450.000 & 55 & 3 & 11 \\
\hline Erigha Ernanda & 9.000 .000 & 60 & 3 & 18 \\
\hline Audi Aziz & 750.000 & 90 & 3 & 14 \\
\hline Liana Leen & 2.800 .000 & 65 & 5 & 8 \\
\hline Jovi Wijaya & 750.000 & 95 & 3 & 4 \\
\hline Buddy Octavius & 4.500 .000 & 100 & 3 & 12 \\
\hline Ivan Nico & 3.500 .000 & 80 & 4 & 3 \\
\hline Evan Heriansyah & 2.000 .000 & 70 & 3 & 14 \\
\hline $\begin{array}{l}\text { Fajarian } \\
\text { Nawangga }\end{array}$ & 1.000 .000 & 80 & 2 & 3 \\
\hline $\begin{array}{l}\text { Muhammad } \\
\text { Reza }\end{array}$ & 800.000 & 60 & 1 & 11 \\
\hline Risky Bayu & 2.500 .000 & 55 & 2 & 2 \\
\hline $\begin{array}{l}\text { Muhammad } \\
\text { Juliano }\end{array}$ & 350.000 & 60 & 5 & 14 \\
\hline
\end{tabular}

Sumber: Hasil Penelitian (2021)

Dalam penentuan rating kecocokan maka nilai dari masing-masing kriteria dimasukan kedalam tabel rating kecocokan yang telah disesuaikan dengan nilai dari tabel kriteria.

Tabel 6. Rating Kecocokan

\begin{tabular}{|c|c|c|c|c|}
\hline \multirow{2}{*}{ NAMA } & \multicolumn{4}{|c|}{ KRITERIA } \\
\cline { 2 - 5 } & $\begin{array}{c}\text { Penghasi } \\
\text { lan } \\
\text { Orang } \\
\text { Tua }\end{array}$ & $\begin{array}{c}\text { Total } \\
\text { Nilai } \\
\text { Semest } \\
\text { er }\end{array}$ & $\begin{array}{c}\text { Tanggun } \\
\text { gan } \\
\text { Orang } \\
\text { Tua }\end{array}$ & $\begin{array}{c}\text { Ranki } \\
\text { ng } \\
\text { Kelas }\end{array}$ \\
\hline Jaya Kusuma & 5 & 4 & 3 & 5 \\
\hline Rasyid Alvian & 4 & 3 & 5 & 3 \\
\hline
\end{tabular}

\begin{tabular}{|l|l|l|l|l|}
\hline Una Wardani & 3 & 3 & 3 & 3 \\
\hline $\begin{array}{l}\text { Eva Natashya } \\
\text { Putri }\end{array}$ & 4 & 5 & 2 & 4 \\
\hline Dini Nuarini & 1 & 1 & 2 & 4 \\
\hline Laura Natazhya & 5 & 4 & 2 & 4 \\
\hline $\begin{array}{l}\text { Antonius } \\
\text { Lumban Gaol }\end{array}$ & 2 & 2 & 1 & 5 \\
\hline Rudy Chandra & 5 & 4 & 2 & 4 \\
\hline Julian Pakpahan & 5 & 2 & 2 & 4 \\
\hline $\begin{array}{l}\text { Arif Taufik } \\
\text { Ritonga }\end{array}$ & 4 & 5 & 3 & 3 \\
\hline $\begin{array}{l}\text { Rachman } \\
\text { Fadillah }\end{array}$ & 3 & 3 & 5 & 4 \\
\hline Fauzi Fuad & 5 & 4 & 3 & 3 \\
\hline Dwi Prasetya & 4 & 3 & 3 & 3 \\
\hline Tri Budiawan & 5 & 2 & 3 & 3 \\
\hline Erigha Ernanda & 1 & 2 & 3 & 2 \\
\hline Audi Aziz & 4 & 4 & 3 & 3 \\
\hline Liana Leen & 3 & 3 & 5 & 4 \\
\hline Jovi Wijaya & 4 & 5 & 3 & 5 \\
\hline Buddy Octavius & 2 & 5 & 3 & 3 \\
\hline Ivan Nico & 2 & 4 & 4 & 5 \\
\hline Evan Heriansyah & 3 & 3 & 3 & 3 \\
\hline $\begin{array}{l}\text { Fajarian } \\
\text { Nawangga }\end{array}$ & 1 & 4 & 2 & 5 \\
\hline $\begin{array}{l}\text { Muhammad } \\
\text { Reza }\end{array}$ & 4 & 2 & 1 & 3 \\
\hline Risky Bayu & 3 & 2 & 2 & 5 \\
\hline $\begin{array}{l}\text { Muhammad } \\
\text { Juliano }\end{array}$ & 5 & 2 & 5 & 3 \\
\hline $\begin{array}{l}\text { Sumber: Hail Pena } \\
\text { Iajar }\end{array}$ & 5 & & \\
\hline
\end{tabular}

Sumber: Hasil Penelitian (2021)

Nilai dari hasil tabel kecocokan kemudian dibuat dalam bentuk matriks sebagai berikut:

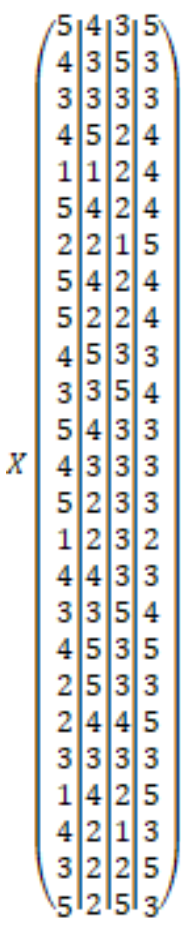

Sumber: Hasil Penelitian (2021):

Membuat Normalisasi Matrik berdasasrkan persamaan yang disesuaikan dengan jenis atribut 
(atribut keuntungan dan atribut biaya ) sehingga diperoleh matriks ternormalisai $\mathrm{R}$.

Tabel 7. Penentuan Cost atau Benefit

\begin{tabular}{|c|c|c|}
\hline Kriteria & Benefit & Cost \\
\hline Penghasilan Orang Tua & $\bar{V}$ & - \\
\hline Total Nilai Semester & $\mathrm{V}$ & - \\
\hline Tanggungan Orang Tua & $\mathrm{V}$ & - \\
\hline Ranking Kelas & $\mathrm{V}$ & - \\
\hline
\end{tabular}

Menentukan Nilai R dengan rumus sebagai berikut:

$R_{i j}=\frac{X_{i j}}{\operatorname{Max} R_{i j}}$ jika atribut bernilai Benefit.

$R_{i j}=\frac{\operatorname{Min} R_{i j}}{X_{i j}}$ jika atribut bernilai Cost

1. Untuk Kriteria Penghasilan Orang Tua merupakan atribut Benefit sebab semakin Besar Nilai Maka semakin baik.

\begin{tabular}{|c|c|c|}
\hline $\begin{array}{l}\text { Alternatif } 1 \\
R_{11}=\frac{5}{5}=1\end{array}$ & $\begin{array}{l}\text { Alternatif } 2 \\
R_{21}=\frac{4}{5}=0,8\end{array}$ & $\begin{array}{l}\text { Alternatif } 3 \\
R_{31}=\frac{3}{5}=0,6\end{array}$ \\
\hline $\begin{array}{l}\text { Alternatif } 4 \\
R_{41}=\frac{4}{5}=0,8\end{array}$ & $\begin{array}{l}\text { Alternatif } 5 \\
R_{51}=\frac{1}{5}=0,2\end{array}$ & $\begin{array}{l}\text { Alternatif } 6 \\
\qquad R_{61}=\frac{5}{5}=1\end{array}$ \\
\hline $\begin{array}{l}\text { Alternatif } 7 \\
R_{71}=\frac{2}{5}=0,4\end{array}$ & $\begin{array}{l}\text { Alternatif } 8 \\
\qquad R_{81}=\frac{5}{5}=1\end{array}$ & $\begin{array}{l}\text { Alternatif } 9 \\
\qquad R_{91}=\frac{5}{5}=1\end{array}$ \\
\hline $\begin{array}{l}\text { Alternatif } 10 \\
R_{101}=\frac{4}{5}=0,8\end{array}$ & $\begin{array}{l}\text { Alternatif } 11 \\
R_{111}=\frac{3}{5}=0,6\end{array}$ & $\begin{array}{l}\text { Alternatif } 12 \\
R_{121}=\frac{5}{5}=1\end{array}$ \\
\hline $\begin{array}{l}\text { Alternatif } 13 \\
R_{131}=\frac{4}{5}=0,8\end{array}$ & $\begin{array}{l}\text { Alternatif } 14 \\
R_{141}=\frac{5}{5}=1\end{array}$ & $\begin{array}{l}\text { Alternatif } 15 \\
R_{151}=\frac{1}{5}=0,2\end{array}$ \\
\hline $\begin{array}{l}\text { Alternatif } 16 \\
R_{161}=\frac{4}{5}=0,8\end{array}$ & $\begin{array}{l}\text { Alternatif } 17 \\
R_{171}=\frac{3}{5}=0,6\end{array}$ & $\begin{array}{l}\text { Alternatif } 18 \\
R_{181}=\frac{4}{5}=0,8\end{array}$ \\
\hline $\begin{array}{l}\text { Alternatif } 19 \\
R_{191}=\frac{2}{5}=0,4\end{array}$ & $\begin{array}{l}\text { Alternatif } 20 \\
R_{201}=\frac{2}{5}=0,4\end{array}$ & $\begin{array}{l}\text { Alternatif } 21 \\
R_{211}=\frac{3}{5}=0,6\end{array}$ \\
\hline $\begin{array}{l}\text { Alternatif } 22 \\
R_{221}=\frac{1}{5}=0,2\end{array}$ & $\begin{array}{l}\text { Alternatif } 23 \\
R_{231}=\frac{4}{5}=0,8\end{array}$ & $\begin{array}{l}\text { Alternatif } 24 \\
R_{241}=\frac{3}{5}=0,6\end{array}$ \\
\hline $\begin{array}{l}\text { Alternatif } 25 \\
R_{251}=\frac{5}{5}=1\end{array}$ & & \\
\hline
\end{tabular}

\section{Sumber: Hasil Penelitian (2021)}

2. Untuk kriteria Total Nilai Semester merupakan benefit sebab semakin tinggi nilai semakin baik.

\begin{tabular}{|c|c|c|}
\hline $\begin{array}{l}\text { Alternatif } 1 \\
R_{12}=\frac{4}{5}=0,8\end{array}$ & $\begin{array}{l}\text { Alternatif } 2 \\
R_{22}=\frac{3}{5}=0,6\end{array}$ & $\begin{array}{l}\text { Alternatif } 3 \\
R_{32}=\frac{1}{5}=0,2\end{array}$ \\
\hline $\begin{array}{l}\text { Alternatif } 4 \\
\qquad R_{42}=\frac{5}{5}=1\end{array}$ & $\begin{array}{l}\text { Alternatif } 5 \\
R_{52}=\frac{1}{5}=0,2\end{array}$ & $\begin{array}{l}\text { Alternatif } 6 \\
R_{62}=\frac{4}{5}=0,8\end{array}$ \\
\hline $\begin{array}{l}\text { Alternatif } 7 \\
R_{72}=\frac{2}{5}=0,4\end{array}$ & $\begin{array}{l}\text { Alternatif } 8 \\
R_{82}=\frac{4}{5}=0,8\end{array}$ & $\begin{array}{l}\text { Alternatif } 9 \\
R_{92}=\frac{2}{5}=0,4\end{array}$ \\
\hline $\begin{array}{l}\text { Alternatif } 10 \\
\qquad R_{102}=\frac{5}{5}=1\end{array}$ & $\begin{array}{l}\text { Alternatif } 11 \\
R_{112}=\frac{3}{5}=0,6\end{array}$ & $\begin{array}{l}\text { Alternatif } 12 \\
R_{122}=\frac{4}{5}=0,8\end{array}$ \\
\hline $\begin{array}{l}\text { Alternatif } 13 \\
R_{132}=\frac{3}{5}=0,6\end{array}$ & $\begin{array}{l}\text { Alternatif } 14 \\
R_{142}=\frac{2}{5}=0,4\end{array}$ & $\begin{array}{l}\text { Alternatif } 15 \\
R_{152}=\frac{2}{5}=0,4\end{array}$ \\
\hline $\begin{array}{l}\text { Alternatif } 16 \\
R_{162}=\frac{4}{5}=0,8\end{array}$ & $\begin{array}{l}\text { Alternatif } 17 \\
R_{172}=\frac{3}{5}=0,6\end{array}$ & $\begin{array}{l}\text { Alternatif } 18 \\
\qquad R_{182}=\frac{5}{5}=1\end{array}$ \\
\hline $\begin{array}{l}\text { Alternatif } 19 \\
R_{192}=\frac{5}{5}=1\end{array}$ & $\begin{array}{l}\text { Alternatif } 20 \\
R_{202}=\frac{4}{5}=0,8\end{array}$ & $\begin{array}{l}\text { Alternatif } 21 \\
R_{212}=\frac{3}{5}=0,6\end{array}$ \\
\hline $\begin{array}{l}\text { Alternatif } 22 \\
R_{222}=\frac{4}{5}=0,8\end{array}$ & $\begin{array}{l}\text { Alternatif } 23 \\
R_{232}=\frac{2}{5}=0,4\end{array}$ & $\begin{array}{l}\text { Alternatif } 24 \\
R_{242}=\frac{2}{5}=0,4\end{array}$ \\
\hline $\begin{array}{l}\text { Alternatif } 25 \\
R_{252}=\frac{2}{5}=0,4\end{array}$ & & \\
\hline
\end{tabular}

Sumber: Hasil Penelitian (2021)

3. Kriteria Untuk Tanggungan Orang Tua merupakan benefit sebab semakin tinggi nilai semakin baik.

\begin{tabular}{|c|c|c|}
\hline $\begin{array}{l}\text { Alternatif } 1 \\
R_{13}=\frac{3}{5}=0,6\end{array}$ & $\begin{array}{l}\text { Alternatif } 2 \\
R_{23}=\frac{5}{5}=1\end{array}$ & $\begin{array}{l}\text { Alternatif } 3 \\
R_{33}=\frac{3}{5}=0,6\end{array}$ \\
\hline $\begin{array}{l}\text { Alternatif } 4 \\
R_{43}=\frac{2}{5}=0,4\end{array}$ & $\begin{array}{l}\text { Alternatif } 5 \\
R_{53}=\frac{2}{5}=0,4\end{array}$ & $\begin{array}{l}\text { Alternatif } 6 \\
R_{63}=\frac{2}{5}=0,4\end{array}$ \\
\hline $\begin{array}{l}\text { Alternatif } 7 \\
R_{73}=\frac{1}{5}=0,2\end{array}$ & $\begin{array}{l}\text { Alternatif } 8 \\
R_{83}=\frac{2}{5}=0,4\end{array}$ & $\begin{array}{l}\text { Alternatif } 9 \\
R_{93}=\frac{2}{5}=0,4\end{array}$ \\
\hline $\begin{array}{l}\text { Alternatif } 10 \\
R_{103}=\frac{3}{5}=0,6\end{array}$ & $\begin{array}{l}\text { Alternatif } 11 \\
\qquad R_{113}=\frac{5}{5}=1\end{array}$ & $\begin{array}{l}\text { Alternatif } 12 \\
R_{123}=\frac{3}{5}=0,6\end{array}$ \\
\hline $\begin{array}{l}\text { Alternatif } 13 \\
R_{133}=\frac{3}{5}=0,6\end{array}$ & $\begin{array}{l}\text { Alternatif } 14 \\
R_{143}=\frac{3}{5}=0,6\end{array}$ & $\begin{array}{l}\text { Alternatif } 15 \\
R_{153}=\frac{3}{5}=0,6\end{array}$ \\
\hline $\begin{array}{l}\text { Alternatif } 16 \\
R_{163}=\frac{3}{5}=0,6\end{array}$ & $\begin{array}{l}\text { Alternatif } 17 \\
\qquad R_{173}=\frac{5}{5}=1\end{array}$ & $\begin{array}{l}\text { Alternatif } 18 \\
R_{183}=\frac{3}{5}=0,6\end{array}$ \\
\hline Alternatif 19 & Alternatif 20 & Alternatif 21 \\
\hline
\end{tabular}




\begin{tabular}{|l|l|l|}
\hline$R_{193}=\frac{3}{5}=0,6$ & $R_{203}=\frac{4}{5}=0,8$ & $R_{213}=\frac{3}{5}=0,6$ \\
\hline $\begin{array}{l}\text { Alternatif } 22 \\
R_{223}=\frac{2}{5}=0,4\end{array}$ & $\begin{array}{c}\text { Alternatif } 23 \\
R_{233}=\frac{1}{5}=0,2\end{array}$ & \begin{tabular}{c}
$R_{243}=\frac{2}{5}=0,4$ \\
\hline $\begin{array}{l}\text { Alternatif } 25 \\
R_{253}=\frac{5}{5}=1\end{array}$
\end{tabular} \\
\hline
\end{tabular}

Sumber: Hasil Penelitian (2021)

4. Kriteria Untuk Ranking Kelas merupakan benefit sebab semakin tinggi nilai semakin baik

\begin{tabular}{|c|c|c|}
\hline $\begin{array}{l}\text { Alternatif } 1 \\
R_{14}=\frac{5}{5}=1\end{array}$ & $\begin{array}{l}\text { Alternatif } 2 \\
R_{24}=\frac{3}{5}=0,6\end{array}$ & $\begin{array}{l}\text { Alternatif } 3 \\
R_{34}=\frac{3}{5}=0,6\end{array}$ \\
\hline $\begin{array}{l}\text { Alternatif } 4 \\
R_{44}=\frac{4}{5}=0,8\end{array}$ & $\begin{array}{l}\text { Alternatif } 5 \\
R_{54}=\frac{4}{5}=0,8\end{array}$ & $\begin{array}{l}\text { Alternatif } 6 \\
R_{64}=\frac{4}{5}=0,8\end{array}$ \\
\hline $\begin{array}{l}\text { Alternatif } 7 \\
\qquad R_{74}=\frac{5}{5}=1\end{array}$ & $\begin{array}{l}\text { Alternatif } 8 \\
\qquad R_{84}=\frac{4}{5}=0,8\end{array}$ & $\begin{array}{l}\text { Alternatif } 9 \\
\qquad R_{94}=\frac{4}{5}=0,8\end{array}$ \\
\hline $\begin{array}{l}\text { Alternatif } 10 \\
R_{104}=\frac{3}{5}=0,6\end{array}$ & $\begin{array}{l}\text { Alternatif } 11 \\
R_{114}=\frac{4}{5}=0,8\end{array}$ & $\begin{array}{l}\text { Alternatif } 12 \\
R_{124}=\frac{3}{5}=0,6\end{array}$ \\
\hline $\begin{array}{l}\text { Alternatif } 13 \\
R_{134}=\frac{3}{5}=0,6\end{array}$ & $\begin{array}{l}\text { Alternatif } 14 \\
R_{144}=\frac{3}{5}=0,6\end{array}$ & $\begin{array}{l}\text { Alternatif } 15 \\
R_{154}=\frac{2}{5}=0,4\end{array}$ \\
\hline $\begin{array}{l}\text { Alternatif } 16 \\
R_{164}=\frac{3}{5}=0,6\end{array}$ & $\begin{array}{l}\text { Alternatif } 17 \\
R_{174}=\frac{4}{5}=0,8\end{array}$ & $\begin{array}{l}\text { Alternatif } 18 \\
\qquad R_{184}=\frac{5}{5}=1\end{array}$ \\
\hline $\begin{array}{l}\text { Alternatif } 19 \\
R_{194}=\frac{3}{5}=0,6\end{array}$ & $\begin{array}{l}\text { Alternatif } 20 \\
R_{204}=\frac{5}{5}=1\end{array}$ & $\begin{array}{l}\text { Alternatif } 21 \\
R_{214}=\frac{3}{5}=0,6\end{array}$ \\
\hline $\begin{array}{l}\text { Alternatif } 22 \\
\qquad R_{224}=\frac{5}{5}=1\end{array}$ & $\begin{array}{l}\text { Alternatif } 23 \\
R_{234}=\frac{3}{5}=0,6\end{array}$ & $\begin{array}{l}\text { Alternatif } 24 \\
\qquad R_{244}=\frac{5}{5}=1\end{array}$ \\
\hline $\begin{array}{l}\text { Alternatif } 25 \\
R_{254}=\frac{3}{5}=0,6\end{array}$ & & \\
\hline
\end{tabular}

Sumber: Hasil Penelitian (2021)

Dari perhitungan diatas diperoleh matriks sebagai berikut :

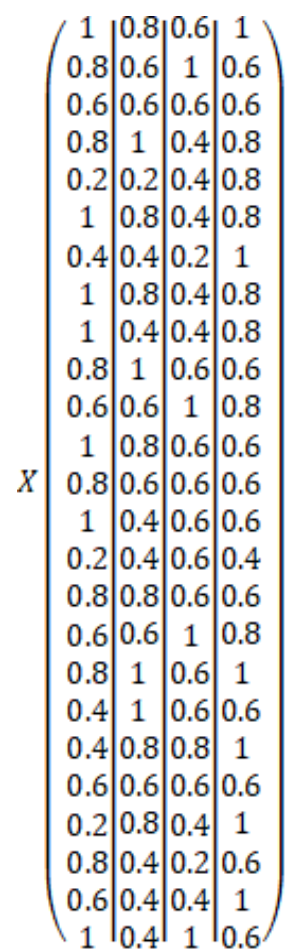

Sumber: Hasil Penelitian (2021)

Untuk mencari nilai dari masing-masing pengisi kuesioner, dalam menentukan rangking dengan menggunakan rumus sebagai berikut.

$V i=\sum_{j=1}^{n i} W_{i} R_{i j}$

$\begin{array}{ll}\mathrm{Vi} & =\text { Nilai akhir dan alternatif } \\ \mathrm{Wi} & =\text { Bobot yang telah ditentukan } \\ \mathrm{Rij} & \quad=\text { Normalisasi Matriks }\end{array}$

Untuk menentukan nilai sampai dengan adalah sebagai berikut:

$\mathrm{V}_{1}=(0,4 * 1)+(0,3 * 0,8)+(0,2 * 0,6)+(0,1 * 1)=0,86$

$\mathrm{V}_{2}=(0,4 * 0,8)+(0,3 * 0,6)+(0,2 * 0,1)+(0,1 * 0,6)=0,76$

$\mathrm{V}_{3}=(0,4 * 0,6)+(0,3 * 0,6)+(0,2 * 0,6)+(0,1 * 0,6)=0,6$

$\mathrm{V}_{4}=(0,4 * 0,8)+(0,3 * 1)+(0,2 * 0,4)+(0,1 * 0,8)=0,78$

$\mathrm{V}_{5}=(0,4 * 0,2)+(0,3 * 0,2)+(0,2 * 0,4)+(0,1 * 0,8)=0,3$

$\mathrm{V}_{6}=(0,4 * 1)+(0,3 * 0,8)+(0,2 * 0,4)+(0,1 * 0,8)=0,8$

$\mathrm{V}_{7}=(0,4 * 0,4)+(0,3 * 0,4)+(0,2 * 2)+(0,1 * 1)=0,42$

$\mathrm{V}_{8}=(0,4 * 1)+(0,3 * 0,8)+(0,2 * 0,4)+(0,1 * 0,8)=0,8$

$\mathrm{V}_{9}=(0,4 * 1)+(0,3 * 0,4)+(0,2 * 0,4)+(0,1 * 0,8)=0,68$

$\mathrm{V}_{10}=(0,4 * 0,8)+\left(0,3^{*} 1\right)+(0,2 * 0,6)+(0,1 * 0,6)=0,8$

$\mathrm{V}_{11}=(0,4 * 0,6)+(0,3 * 0,6)+(0,2 * 1)+(0,1 * 0,8)=0,7$

$\mathrm{V}_{12}=(0,4 * 1)+(0,3 * 0,8)+(0,2 * 0,6)+(0,1 * 0,6)=0,82$

$\mathrm{V}_{13}=(0,4 * 0,8)+(0,3 * 0,6)+(0,2 * 0,6)+(0,1 * 0,6)=0,68$

$\mathrm{V}_{14}=(0,4 * 1)+(0,3 * 0,4)+(0,2 * 0,7)+(0,1 * 0,6)=0,7$

$\mathrm{V}_{15}=(0,4 * 0,2)+(0,3 * 0,4)+(0,2 * 0,6)+(0,1 * 0,4)=0,36$

$\mathrm{V}_{16}=(0,4 * 0,8)+(0,3 * 0,8)+(0,2 * 0,6)+(0,1 * 0,6)=0,74$

$\mathrm{V}_{17}=(0,4 * 0,6)+(0,3 * 0,6)+(0,2 * 1)+(0,1 * 0,8)=0,7$

$\mathrm{V}_{18}=(0,4 * 0,8)+(0,3 * 1)+(0,2 * 0,6)+(0,1 * 1)=0,84$

$\mathrm{V}_{19}=(0,4 * 0,4)+(0,3 * 1)+(0,2 * 0,6)+(0,1 * 0,6)=0,64$

$\mathrm{V}_{20}=(0,4 * 0,4)+(0,3 * 0,8)+(0,2 * 0,8)+(0,1 * 0,1)=0,66$

$\mathrm{V}_{21}=(0,4 * 0,6)+\left(0,3^{*} 0,6\right)+(0,2 * 0,6)+(0,1 * 0,6)=0,6$ 
$\mathrm{V}_{22}=(0,4 * 0,2)+(0,3 * 0,8)+(0,2 * 0,4)+(0,1 * 1)=0,5$

$\mathrm{V}_{23}=(0,4 * 0,8)+(0,3 * 0,4)+(0,2 * 0,2)+(0,1 * 0,6)=0,54$

$\mathrm{V}_{24}=(0,4 * 0,6)+(0,3 * 0,4)+(0,2 * 0,1)+(0,1 * 1)=0,54$

$\mathrm{V}_{25}=(0,4 * 1)+(0,3 * 0,4)+(0,2 * 1)+(0,1 * 0,6)=0,78$

Dari hasil perhitungan nilai sampai maka tabel penentuan rangking dapat dilihat pada tabel di bawah ini

Tabel 8. Penentuan Ranking

\begin{tabular}{|l|c|c|c|}
\hline \multicolumn{1}{|c|}{ NAMA } & $\begin{array}{c}\text { NIL } \\
\text { AI }\end{array}$ & $\begin{array}{c}\text { PRESENT } \\
\text { ASE }\end{array}$ & $\begin{array}{c}\text { RANGK } \\
\text { ING }\end{array}$ \\
\hline Jaya Kusuma & 0,86 & $86 \%$ & 1 \\
\hline Jovi Wijaya & 0,84 & $84 \%$ & 2 \\
\hline Fauzi Fuad & 0,82 & $82 \%$ & 3 \\
\hline Laura Natazhya & 0,80 & $80 \%$ & 4 \\
\hline Rudy Chandra & 0,80 & $80 \%$ & 5 \\
\hline $\begin{array}{l}\text { Arif Taufik } \\
\text { Ritonga }\end{array}$ & 0,80 & $80 \%$ & 6 \\
\hline Eva Natashya Putri & 0,78 & $78 \%$ & 7 \\
\hline $\begin{array}{l}\text { Muhammad } \\
\text { Juliano }\end{array}$ & 0,78 & $78 \%$ & 8 \\
\hline Rasyid Alvian & 0,76 & $76 \%$ & 9 \\
\hline Audi Aziz & 0,74 & $74 \%$ & 10 \\
\hline Rachman Fadillah & 0,70 & $70 \%$ & 11 \\
\hline Tri Budiawan & 0,70 & $70 \%$ & 12 \\
\hline Liana Leen & 0,70 & $70 \%$ & 13 \\
\hline Julian Pakpahan & 0,68 & $68 \%$ & 14 \\
\hline Dwi Prasetya & 0,68 & $68 \%$ & 15 \\
\hline Ivan Nico & 0,66 & $66 \%$ & 16 \\
\hline Buddy Octavius & 0,64 & $64 \%$ & 17 \\
\hline Una Wardani & 0,60 & $60 \%$ & 18 \\
\hline Evan Heriansyah & 0,60 & $60 \%$ & 19 \\
\hline Muhammad Reza & 0,54 & $54 \%$ & 20 \\
\hline Risky Bayu & 0,54 & $54 \%$ & 21 \\
\hline Fajarian Nawangga & 0,50 & $50 \%$ & 22 \\
\hline $\begin{array}{l}\text { Antonius Lumban } \\
\text { Gaol }\end{array}$ & 0,42 & $42 \%$ & 23 \\
\hline Erigha Ernanda & 0,36 & $36 \%$ & 24 \\
\hline Dini Nuarini & 0,30 & $30 \%$ & 25 \\
\hline Suber: Hasi Penein & & & \\
\hline
\end{tabular}

Sumber: Hasil Penelitian (2021)

Dari penentuan prioritas usulan penentuan pemberian beasiswa dengan menggunakan metode Simple Additive Weight (SAW) maka diperoleh 5 peringkat siswa terbaik yang berhak untuk mendapatkan beasiswa dari SMA PGRI 4 Jakarta Timur, yaitu:

1. Jaya Kusuma dengan hasil perhitungan 0,86 menduduki peringkat pertama.

2. Jovi Wijaya dengan hasil perhitungan 0,84 menduduki peringkat kedua.

3. Fauzi Fuad dengan hasil perhitungan 0,82 menduduki peringkat ketiga.

4. Laura Natazhya dengan hasil perhitungan 0,80 menduduki peringkat keempat.

5. Rudy Chandra dengan hasil perhitungan 0,80 menduduki peringkat kelima..

\section{KESIMPULAN}

Pemberian beasiswa pada siswa dengan metode Simple Additive Weighting dapat menjadi alternatif solusi dalam pemilihan pemberian beasiswa yang dilakukan oleh SMA PGRI 4 Jakarta Timur.

Dari hasil perhitungan dengan menggunakan metode Simple Additive Weighting, siswa yang bernama Jaya Kusuma mendapatkan persentase nilai sebesar $86 \%$ yang hanya berbeda $2 \%$ dari siswa Jovi Wijaya yang berada di peringkat kedua dengan persentase nilai sebesar $84 \%$.

\section{REFERENSI}

Amri, S. (2018). FAKTOR-FAKTOR YANG MEMPENGARUHI KONSUMEN DALAM PENGAMBILAN KEPUTUSAN PEMBELIAN PRODUK GREEN WORLD GLOBAL DI BANDA ACEH. Ihtiyath: Jurnal Manajemen Keuangan Syariah, 2(2). https://doi.org/10.32505/IHTIYATH.V2I2.708

Efendi, R., \& Ali, G. (2019). Analisis Multi Criterion Decision Making Pada Decision Support System Untuk Pengambilan Keputusan Penentuan Penerima Beasiswa. JOISIE (Journal Of Information Systems And Informatics Engineering), 1(1), 1-4. https://doi.org/10.35145/JOISIE.V1I1.384

Fauzan, R., Indrasary, Y., \& Muthia, N. (2018). Sistem Pendukung Keputusan Penerimaan Beasiswa Bidik Misi di POLIBAN dengan Metode SAW Berbasis Web. Jurnal Online Informatika, 2(2), 79. https://doi.org/10.15575/JOIN.V2I2.101

Handayani, C., \& -, H. (2018). Implementasi Metode Promethee untuk Menentukan Penerima Kartu Indonesia Pintar (KIP) pada Sekolah Menengah Kejuruan. Prosiding Seminar Nasional Multidisiplin, 1, 172-180. Retrieved from

https://ejournal.unwaha.ac.id/index.php/snami/ article/view/286

Karim, J., \& Karim, J. (2018). SISTEM PENDUKUNG KEPUTUSAN PENENTUAN PRIORITAS PEMBANGUNAN MENGGUNAKAN METODE PROMETHEE PADA DESA AYULA KECAMATAN RANDANGAN KABUPATEN POHUWATO PROVINSI GORONTALO. ILKOM Jurnal Ilmiah, 10(1), 86-91. https://doi.org/10.33096/ilkom.v10i1.232.8691

Mulyadi, D., \& Prairawan, D. B. (2020). Penerapan Metode Fuzzy Tsukamoto untuk Kelayakan Penerimaan Beasiswa di Sekolah Menengah Kejuruan (SMK). Teknois: Jurnal Ilmiah Teknologi Informasi Dan Sains, 10(1), 65-80. 
Narti, N., Sriyadi, S., Rahmayani, N., \& Syarif, M. (2019). Pengambilan Keputusan Memilih Sekolah Dengan Metode AHP. Jurnal Informatika, 6(1), 143-150. https://doi.org/10.31294/JI.V6I1.5552

Putra, J. D., Zaliluddin, D., \& Abdurahman, D. (2018). Perancangan Sistem Pendukung Keputusan Kelayakan Penerima Beasiswa Untuk Siswa Tidak Mampu Dengan Metode AHP Menggunakan Visual Basic 2010. JSiI (Jurnal Sistem Informasi), 5(2). https://doi.org/10.30656/JSII.V5I2.780
Saputra, H., Mardiono, E., Stephane, I., \& Purwasih, R. (2021). SELEKSI PENERIMAAN BEASISWA BIDIKMISI PADA STMIK INDONESIA PADANG MENGGUNAKAN METODE (AHP). Jurnal Manajemen Informatika Dan Sistem Informasi, 4(1), 2835. https://doi.org/10.36595/MISI.V4I1.215

Saputra, R. D., Erwandi, D., \& Khoir, K. (2017). Sistem Pendukung Keputusan Penerima Beasiswa Mahasiswa-KU di DPU-DT Priangan Timur Menggunakan Metode Weighted Product(WP). Jurnal VOI (Voice Of Informatics), 6(2), 1-5. 